\title{
Monimuotoisuusvyöhyke pellolle vai metsän puolelle?
}

Antti Miettinen ja Kari Hyytiäinen

MTT Taloustutkimus, Luutnantintie 13,00410 Helsinki, etunimi.sukunimi@mtt.fi

\section{Tiivistelmä}

Luonnon biologinen monimuotoisuus on vähentynyt maatalousympäristöissä tehostuneen ja yksipuolistuneen peltoviljelyn seurauksena. Monimuotoisuuden vähenemiseen on pyritty vastaamaan maatalouden ympäristötuen toimenpiteillä, mutta uusia ja taloudellisesti tehokkaita keinoja monimuotoisuuden turvaamiseksi tarvitaan. Tässä tutkimuksessa vertailtiin kustannuksia ja tulonmenetyksiä, jotka aiheutuvat yksityiselle maanomistajalle pellon reunaan ja peltoon rajoittuvan metsän reunaan perustettavista monimuotoisuusvyöhykkeistä. Myös peltoon rajoittuvaan metsään sijoitettavan monimuotoisuusvyöhykkeen tarkoituksena on lisätä maatalousympäristön lajiston monimuotoisuutta ja luoda erityisesti pölyttäjähyönteisille sopivia niittymäisiä elinympäristöjä. Monimuotoisuusvyöhykkeiden aiheuttamien kustannusten ja tulonmenetysten suuruus saadaan selville, kun hyvän metsänhoidon ja maatalouden mukaisista nettotulojen nykyarvoista vähennetään monimuotoisuusvyöhykkeiden nettotulojen nykyarvot. Metsän puolelle perustettavan monimuotoisuusvyöhykkeen yksityistaloudellisissa kustannuksissa oli suurta vaihtelua, joka aiheutui vaihtelusta metsän tuotoskyvyssä sekä metsän lähtötilassa ja -rakenteessa. Mikäli rehuviljan hinnan voidaan olettaa jäävän pysyvästi matalaksi, kannattaa maanomistajan perustaa monimuotoisuusvyöhykkeet ennemmin pellon reunaan kuin metsän puolelle.

Asiasanat: maatalouden ympäristötuki, maatalousluonnon biologinen monimuotoisuus, metsätalous, pölyttäjähyönteiset 


\section{Johdanto}

Maatalouden erikoistuminen 1900-luvun puolivälistä alkaen sekä nautakarjatilojen lukumäärän vähentyminen ja alueellinen keskittyminen ovat lisänneet yksipuolisessa viljelyssä olevan maatalousmaan pinta-alaa Suomessa. Samalla erilaisten niittyjen ja luonnonlaidunten sekä avo-ojien ja pellonpientareiden pinta-alat ovat vähentyneet. Vuoden 2009 alussa poistunut tilatuen kesannointivelvoite tehostaa entisestään peltojen käyttöä. Merkittävä haittavaikutus tehostuneesta ja yksipuolistuneesta peltoviljelystä on maataloustuotannon kestävyyden ja luonnon biologisen monimuotoisuuden kannalta tärkeän eläinlajiston - kuten ekosysteemipalveluita tuottavien pölyttäjähyönteisten - elinolosuhteiden heikkeneminen.

Yksityisellä maanomistajalla ei yleensä ole taloudellista kannustinta tehdä monimuotoisuutta edistäviä toimenpiteitä ilman, että julkinen valta puuttuu markkinoiden toimintaan. Tämä johtuu siitä, että monimuotoisuudelle ei ole olemassa markkinoita, vaan luonnon biologinen monimuotoisuus on julkishyödyke, jonka hyödyt tulevat maksutta kaikille ja kustannukset jäävät monimuotoisuushyötyjen tuottajien maksettaviksi. Julkinen valta voi kuitenkin toimillaan muuttaa tätä asetelmaa. Se voi pakottaa kansalaiset maksamaan (veroina tai muina maksuina) maatalousympäristöjen monimuotoisuuden lisääntymisestä ja maksaa korvauksen (esim. ympäristötukea) maanomistajille, jotta nämä tekevät monimuotoisuutta edistäviä toimenpiteitä.

Maatalouden ympäristötuki onkin keskeinen väline luonnon monimuotoisuuden säilyttämiseksi maatalousmailla. Ympäristötuen toimenpiteiden lisäksi tehostuneen peltoviljelyn takia taantunutta kasvi- ja eläinlajistoa voidaan palauttaa myös yksi- ja monivuotisilla viherkesannoilla sekä viljeltäviä kasvilajeja ja viljelykiertoja monipuolistamalla.

Useat ympäristötuen toimenpiteet on kuitenkin suunnattu lähinnä pelloilta vesistöihin kulkeutuvien ravinnepäästöjen vähentämiseksi. Maatalouden ympäristötuen vaikuttavuuden seurantatutkimusten mukaan nykyiset ympäristötuen toimenpiteet ovat kokonaisuudessaan riittämättömiä ja vaikutuksiltaan osin ristiriitaisia maatalousympäristön monimuotoisuuden turvaamiseksi (Kuussaari ym., 2008). Lisäksi maatalouden ympäristötuen toimenpiteitä leimaa tehottomuus suhteessa ympäristötukeen käytettyyn rahamäärään (Grönroos ym., 2007; Kuussaari ym., 2008).

Tässä tutkimuksessa vertaillaan kahden monimuotoisuustoimenpiteen kustannuksia maanomistajan näkökulmasta. Tarkasteltavat toimenpiteet ovat pellon reunaan perustettava $25 \mathrm{~m}$ leveä monimuotoisuusvyöhyke sekä peltoon rajoittuvan metsän reunaan perustettava 25 m leveä monimuotoisuusvyöhyke. Myös jälkimmäisen toimenpiteen tarkoituksena on lisätä maatalousympäristön lajien monimuotoisuutta ja luoda erityisesti pölyttäjähyönteisille sopivia niittymäisiä elinympäristöjä peltoihin rajoittuvien metsien reunoihin. Tällaista koeasetelmaa ei ole aiemmin tutkittu.

Monimuotoisuusvyöhykkeet aiheuttavat maanomistajille tulonmenetyksiä, koska osa aiemmin viljelykasvien ja puuntuotantoon käytetystä maa-alasta siirtyy nyt monimuotoisuusvyöhykkeeksi. Lisäksi monimuotoisuusvyöhykkeet edellyttävät säännöllisiä hoitotoimia, joista aiheutuu maanomistajille kustannuksia. Oletuksena on, että rationaalinen maanomistaja ottaa toimenpiteen käyttöön, jos julkinen valta korvaa toimenpiteestä aiheutuvat kustannukset ja tulonmenetykset. Vaihtoehtoisten toimenpiteiden kustannusvaikutusten vertaileminen tuottaa politiikantekijöille tietoa vaadittavan kompensaation minimitasosta, jolla rationaalinen maanomistaja ottaa vapaaehtoisen monimuotoisuustoimenpiteen käyttöön.

\section{Aineisto ja menetelmät}

Tutkimuksessa vertaillaan pellon reunaan ja peltoon rajoittuvan metsän reunaan perustettavien monimuotoisuusvyöhykkeiden aiheuttamia kustannuksia ja tulonmenetyksiä yksityisen maanomistajan kannalta. Oletuksena on, että rationaalinen maanomistaja noudattaa pelloillaan hyvän maatalouden ja ympäristönhoidon vaatimuksia sekä metsien puolella metsänhoidollisia suosituksia ja maksimoi pelto- ja metsähehtaareilta saatavan nettotulovirran nykyarvoa. Monimuotoisuusvyöhykkeiden perustamis- ja hoitokustannukset aiheuttavat maanomistajalle lisäkustannuksia ja tulonmenetyksiä (ja täten pienentävät nettotulovirtojen nykyarvoa). Aiemmin pelkästään maa- tai metsätaloustuotantoon käytetyt alueet siirtyvät sadon ja monimuotoisuushyötyjen yhteistuotantoon. Monimuotoisuusvyöhykkeiden aiheuttamien kustannusten ja tulonmenetysten suuruus saadaan selville, kun hoitosuositusten mukaan käsiteltyjen peltojen ja metsien nettotulojen nykyarvosta vähennetään monimuotoisuusvyöhykkeen nettotulojen nykyarvo. 


\section{Kuvio 1. Pellon reunaan ja metsän puolelle perustetut monimuotoisuusvyöhykkeet}

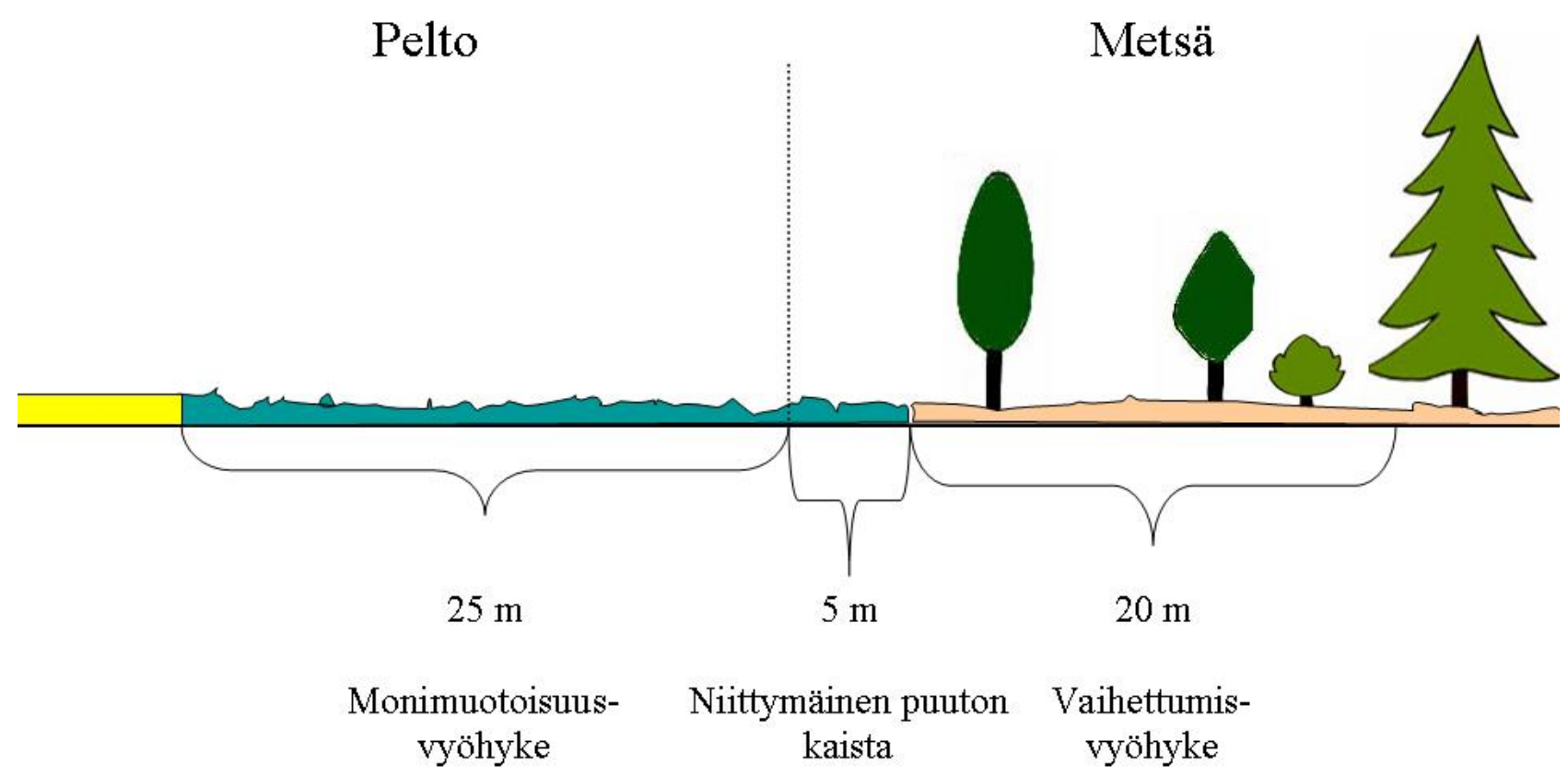

Pellon monimuotoisuusvyöhyke: Rehuohrapellon reunaan perustetaan $25 \mathrm{~m}$ leveä monimuotoisuusvyöhyke (kuvio 1). Perustamiskustannukset koostuvat pelkästään heinäkasvien siemenkustannuksesta, koska monimuotoisuusvyöhyke voidaan perustaa suojaviljaan kylvön yhteydessä. Pellon monimuotoisuusvyöhykkeellä ei käytetä torjunta-aineita eikä sitä lannoiteta. Pellon monimuotoisuusvyöhyke niitetään vuosittain ja heinä korjataan pois. Niitosta ja korjuusta aiheutuu kustannuksia, mutta siltä saadaan myös tuloja mikäli sato voidaan käyttää säilörehuksi tai kuivaheinäksi. Alustavissa laskelmissa säilörehun hehtaarisadon arvoksi oletettiin 30 prosenttia 14000 kg:n hehtaarisadon arvosta. Lisäksi oletettiin, että pellolle perustetulle monimuotoisuusvyöhykkeelle maksetaan tilatuki ja luonnonhaittakorvaus.

Monimuotoisuusvyöhykkeeltä saatavien nettotulojen lisäksi pellolle perustettavan monimuotoisuusvyöhykkeen aiheuttamien tulonmenetysten suuruus riippuu pellon tuottokyvystä, pellolla viljeltävästä kasvista sekä sen tuottaman katetuoton suuruudesta. Esimerkkilaskelmissa oletettiin, että keskimääräinen rehuohran hehtaarisato on $4000 \mathrm{~kg}$. Rehuohran katetuotot laskettiin erilaisilla viljan hintaoletuksilla (100-200 €/tn). Laskelmissa oletettiin, että viljelijä ostaa työt ulkopuolisilta urakoitsijoilta. Muuttuvien kustannusten ja työkustannusten arvioinnissa hyödynnettiin Tuottopehtoria (ProAgria Keskusten Liitto, 2009) sekä TTS tutkimuksen raportoimia konetyön kustannuksia ja tilastollisia urakointihintoja (Palva, 2009).

Kokonaisuudessaan pellolle perustettavan monimuotoisuusvyöhykkeen aiheuttamat kustannukset ja tulonmenetykset laskettiin vertaamalla rehuohran ja monimuotoisuusvyöhykkeen hehtaarikohtaisten katetuottojen nykyarvojen erotusta.

Metsän monimuotoisuusvyöhyke: Pellolle perustettavan monimuotoisuusvyöhykkeen vaihtoehtona on metsän puolelle perustettava, myös 25 m leveä monimuotoisuusvyöhyke (kuvio 1). Metsän puolella oleva vyöhyke koostuu 5 m leveästä niittymäisestä osasta sekä 20 m leveästä vaihettumisvyöhykkeestä. Metsän puolelle perustettavien monimuotoisuusvyöhykkeiden aiheuttamien kustannusten ja tulonmenetysten arviointia varten Jokioisille ja Vihtiin perustettiin yhteensä 30 koealaa, joiden puusto inventoitiin ja joiden hakkuita ja metsänkäsittelyjä simuloitiin SIMO-simulaattorin (http://www.simo-project.org/) avulla. Simuloinnissa ole- 
tuksina oli kaksi erilaista metsien käsittelytapaa, joiden perusteella metsäkoealueilta saatujen nettotulojen nykyarvoja verrattiin keskenään monimuotoisuusvyöhykkeiden aiheuttamien kustannusten ja tulonmenetysten laskemiseksi.

Ensimmäisessä simuloinnissa oletettiin, että monimuotoisuusvyöhykkeitä ei perusteta ja että koealueita käsitellään vallitsevan käytännön (Metsätalouden kehittämiskeskus Tapion hyvän metsänhoidon suositukset) mukaisesti. Toisessa simuloinnissa puolestaan oletettiin, että lähinnä peltoa oleva 5 metriä leveä kaista hakataan heti paljaaksi ja pidetään puuttomana viiden vuoden välein toistuvin raivauksin. Syvempänä metsässä oleva 20 metriä leveä vaihettumisvyöhyke harvennetaan $\mathrm{n} .8 \mathrm{~m} / \mathrm{h} a: n$ pohjapinta-alaan. Vaihettumisvyöhykkeen puustoa käsitellään poimintahakkuin 20 vuoden välein ja puustoa pyritään ohjaamaan eriikäiseksi sekapuustoksi, jossa lehtipuiden osuus on suuri. Metsän puolelle pellon reunaan perustettavan monimuotoisuusvyöhykkeen aiheuttamat kustannukset ja tulonmenetykset laskettiin vertaamalla Tapion suositusten sekä raivausten ja poimintahakkuiden tuloksena saatavien nettotulovirtojen nykyarvojen erotusta.

\section{Alustavat tulokset ja johtopäätökset}

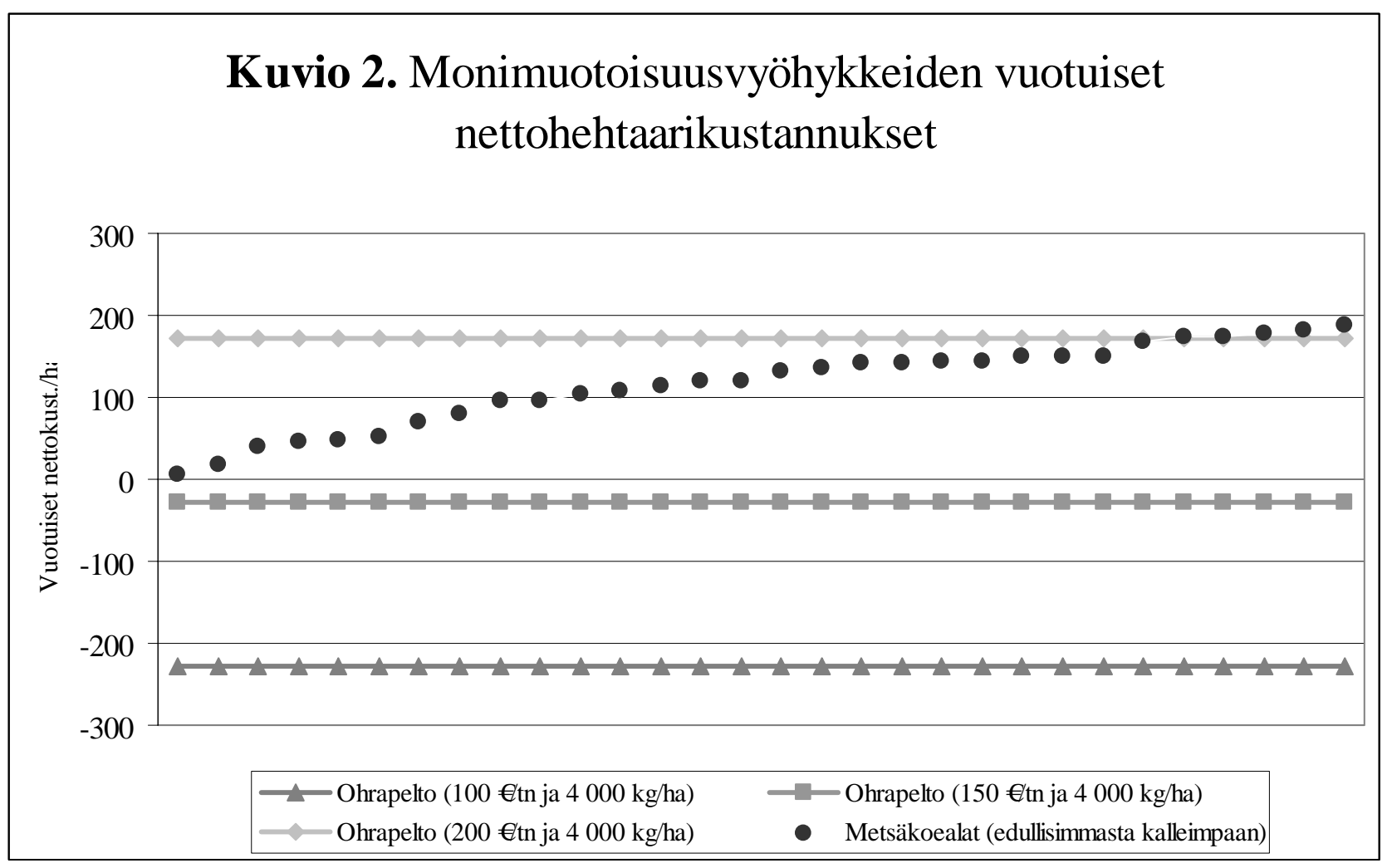

Kuviossa 2 metsäkoealat on järjestetty monimuotoisuuden tuotantokustannusten perusteella edullisimmasta kalleimpaan. Monimuotoisuusvyöhykkeen perustaminen ja hoito aiheuttaa kustannuksia kaikilla 30 koealalla. Kustannuksissa on kuitenkin merkittävää vaihtelua. Vuotuiset nettohehtaarikustannukset vaihtelevat 7 eurosta 188 euroon. Kustannusten vaihtelu koealojen välillä johtuu koealoilla olevan puuston ikä- ja rakenne-eroista monimuotoisuuskaistan perustamishetkellä sekä metsien erilaisesta tuottokyvystä. Puutavaralajien hintojen oletettiin pysyvän muuttumattomina.

Rehuohrapellolle perustettujen monimuotoisuusvyöhykkeiden nettohehtaarikustannukset on esitetty kolmelle eri hintaoletukselle kuviossa 2. Pellon tuottokyky oletetaan vakioksi (4 $000 \mathrm{~kg}$ ). Jos rehuohran hinta on $100 € /$ tn tai $150 € /$ tn, viljelijälle ei tulosten mukaan aiheudu pellolle perustetusta monimuotoisuusvyöhykkeestä lainkaan nettokustannuksia. Sen sijaan viljelijä saa monimuotoisuusvyöhykkeeltä tuloja, joiden vuotuinen hehtaarikohtainen nettotuotto näyttää ylittävän rehuohran viljelystä saatavan vuotuisen hehtaarikohtaisen nettotuoton. Jos rehuohran keskihinnan oletetaan asettuvan tulevaisuudessa nykyistä huomattavasti korkeammalle tasolle (200 €/tn), monimuotoisuusvyöhykkeen vuotuiset nettohehtaarikustannukset ovat 172 euroa suuremmat kuin rehuohran viljelyssä. 
Laskelmissa oletettiin, että pellolle perustettavalle monimuotoisuusvyöhykkeelle maksetaan tilatuki ja luonnonhaittakorvaus. Jos rehuohran hinta on alle $158 €$ /tn, viljelijän kannattaa laskelmien mukaan perustaa monimuotoisuusvyöhyke ohrapellolle ilman erillistä yhteiskunnan maksamaa ympäristötukea. Mikäli rehuohran hinta on tätä kalliimpi, rationaalinen viljelijä vaatii taloudellista kompensaatiota perustaakseen pellolle monimuotoisuusvyöhykkeen. Jos rehuohran hinta on esimerkiksi $200 € / \mathrm{tn}$, vaadittu kompensaatio on vähintään $172 € /$ ha.

Kaiken kaikkiaan tulosten perusteella näyttää siltä, että mikäli rehuviljan hinta jää pysyvästi matalaksi, maanomistajan kannattaa perustaa monimuotoisuusvyöhykkeet pellolle. Tulokseen sisältyy kuitenkin varaumia, sillä analyysissä ei ole toistaiseksi otettu huomioon hintaepävarmuutta. Sekä raakapuun että viljojen hinnat ovat parin viime vuoden aikana vaihdelleet huomattavasti.

Kuviosta 2 ilmenee, että jos viljan hinta kohoaa kovin korkeaksi, tulevat ainakin huonompituottoisilla metsämailla olevat monimuotoisuuskaistat viljelijälle edullisemmaksi kuin pellon puolelle perustettavat monimuotoisuuskaistat. On kuitenkin muistettava, että metsän puolelle perustettavien monimuotoisuusvyöhykkeiden perustaminen edellyttää metsien kasvun ja puun kysynnän ennustamista pitkälle tulevaisuuteen. Koska ympäristötuen sitoumuskausi on tyypillisesti 5 vuotta, pellolle perustettu monimuotoisuusvyöhyke voidaan ottaa tarpeen vaatiessa suhteellisen nopeasti uudelleen viljelyyn. Sen sijaan metsän puolelle perustettu monimuotoisuusvyöhyke ei välttämättä palaudu kovin nopeasti tehokkaaseen puuntuotantoon, koska metsien kasvu on hidasta.

Lisäksi on huomattava, että vertailtujen toimenpiteiden vaikuttavuudesta ja kustannustehokkuudesta ei voida vielä sanoa mitään. Niiden arvioimiseksi tarvitaan jatkotutkimuksia pellon ja metsän puolelle perustettujen monimuotoisuusvyöhykkeiden vaikuttavuudesta esimerkiksi pölyttäjähyönteisten elinolosuhteisiin ja kantoihin. Vasta sitten pystytään selvittämään voidaanko monimuotoisuushyödyt tuottaa kustannustehokkaammin pellolla vai metsän puolella.

\section{Kiitokset}

Kiitämme Antti Mäkistä (HY) metsäkoealojen käsittelyjen simuloinneista ja Kauko Koikkalaista (MTT) katetuottolaskelmien kommentoinnista.

\section{Kirjallisuus}

Grönroos, J., Hietala-Koivu, R., Kuussaari, M., Laitinen, P., Lankoski, J., Lemola, R., Miettinen, A., Perälä, P., Puustinen, M., Schulman, A., Salo, T., Siimes, K. \& Turtola, E. 2007. Analyysi maatalouden ympäristötukijärjestelmästä 2000-2006. Suomen ympäristö 19/2007. Suomen ympäristökeskus, Helsinki.

Kuussaari, M., Heliölä, J., Tiainen, J. \& Helenius, J. (toim.) 2008. Maatalouden ympäristötuen merkitys luonnon monimuotoisuudelle ja maisemalle: MYTVAS-loppuraportti 2000-2006. Suomen ympäristö 4/2008. Suomen ympäristökeskus, Helsinki.

Palva, R. 2009. Konetyön kustannukset ja tilastolliset urakointihinnat. TTS tutkimuksen tiedote, Luonnonvara-ala: maatalous 3/2009 (612).

ProAgria Keskusten Liitto. 2009. Tuottopehtori e-julkaisu. Viitattu 27.11.2009. Saatavilla Internetistä: https://www.webwisu.fi/tuottopehtori/index.php?locale=fi 